Economic Systems of Innovation in the Arab Region 



\section{Economic Systems of Innovation in the Arab Region}

Samia Mohamed Nour 


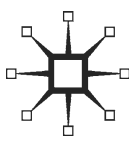

ECONOMIC SYSTEMS OF INNOVATION IN THE ARAB REGION

Copyright @ Samia Mohamed Nour 2016

Softcover reprint of the hardcover 1st edition 2016 978-1-137-46299-2

All rights reserved. No reproduction, copy or transmission of this publication may be made without written permission. No portion of this publication may be reproduced, copied or transmitted save with written permission. In accordance with the provisions of the Copyright, Designs and Patents Act 1988 , or under the terms of any licence permitting limited copying issued by the Copyright Licensing Agency, Saffron House, 6-10 Kirby Street, London EC1N 8TS.

Any person who does any unauthorized act in relation to this publication may be liable to criminal prosecution and civil claims for damages.

First published 2016 by PALGRAVE MACMILLAN

The author has asserted their right to be identified as the author of this work in accordance with the Copyright, Designs and Patents Act 1988.

Palgrave Macmillan in the UK is an imprint of Macmillan Publishers Limited, registered in England, company number 785998, of Houndmills, Basingstoke, Hampshire, RG216XS.

Palgrave Macmillan in the US is a division of Nature America, Inc., One New York Plaza, Suite 4500, New York, NY 10004-1562.

Palgrave Macmillan is the global academic imprint of the above companies and has companies and representatives throughout the world.

ISBN: 978-1-349-69055-8

E-PDF ISBN: 978-1-137-46221-3

DOI: $10.1057 / 9781137462213$

Distribution in the UK, Europe and the rest of the world is by Palgrave Macmillan ${ }^{\circledR}$, a division of Macmillan Publishers Limited, registered in England, company number 785998, of Houndmills, Basingstoke, Hampshire RG21 6XS.

Library of Congress Cataloging-in-Publication Data

Names: Mohamed Nour, Samia, author.

Title: Economic systems of innovation in the Arab region / by Samia Mohamed Nour.

Description: New York, NY : Palgrave Macmillan, [2015] | Includes bibliographical references and index.

Identifiers: LCCN 2015034044 |

Subjects: LCSH: Technological innovations-Economic aspects-Arab countries. | Diffusion of innovations-Arab countries. | Economic development-Arab countries.

Classification: LCC HC498.9.T4 N68 2015 | DDC 338/.06409174927-dc23

LC record available at http://lccn.loc.gov/2015034044

A catalogue record for the book is available from the British Library. 
For my beloved parents, Alawia and Satti 



\section{Contents}

List of Figures $\quad$ ix

List of Tables xvii

Preface xix

Acknowledgments $\quad$ xxiii

Permissions xxvii

List of Abbreviations $\quad$ xxix

Chapter 1 General Introduction 1

Chapter 2 Economic Development Challenges in the Arab Region and the Need for Promoting Systems of Innovation 13

Chapter 3 Conceptual Framework and Literature Review 75

Chapter 4 Overview of National Systems of Innovation in the Arab Countries $\quad 91$

Chapter 5 Overview of Regional Systems of Innovation in the Arab Region 167

Chapter 6 Implications of Poor Systems of Innovation in the Arab Region

$\begin{array}{lll}\text { Chapter } 7 & \text { Summary and Conclusions } & 271\end{array}$

Notes $\quad 285$

$\begin{array}{ll}\text { References } & 293\end{array}$

$\begin{array}{ll}\text { Index } & 305\end{array}$ 



\section{Figures}

2.1 The share in total Arab population in the Arab region (2013) (\%) 22

2.2 The share in total Arab GDP in the Arab region (2012) (\%) 22

2.3 The share of diversified and natural resources-based economies in total Arab population in the Arab region (2013) (\%) 22

2.4 The share of diversified and natural resources-based economies in total Arab GDP in the Arab region (2013) (\%) 23

2.5 GDP per capita in the Arab region (2012) (PPP\$) 23

2.6 Life expectancy, mean years of schooling, expected years of schooling, adult literacy rate, and gross enrollment in education in the Arab region (2003-2013) 24

2.7 Population trend in the Arab region (2000-2015) 24

2.8 Education and health in the Arab region (2003-2012) 25

2.9 Structure of GDP: The share of extractive and manufacturing

2.10 Structure of GDP: The share of extractive and manufacturing industries in GDP in the Arab countries (2000-2012) (\%) 30

2.11 Structure of GDP: The growth rate of extractive and manufacturing industries in GDP in the Arab countries (2005-2012) (\%) 30

2.12 The informal (shadow) economy in the Arab region and World countries (2007) 32

2.13 The informal (shadow) economy in the Arab region (2007) 33

2.14 The informal (shadow) economy in the Arab countries (2007) 33

2.15 Stagnant private investment rates-Private investments as \% of GDP 34

2.16 Value of GDP in the Arab countries (current prices) (2000-2012) 37

2.17 Trend of GDP annual growth rate in the Arab countries (constant prices) (2000-2012) 39

2.18 Trend of annual GDP per capita in the Arab region (1995-2012) 39

2.19 Value and trend of GDP per capita annual growth rate in the Arab region (2011-2012)

2.20 Average annual GDP growth rate in the Arab and World regions (2000-2010) 
2.21 Average annual productivity growth in the Arab and World regions (2000-2010)

2.22 Average annual labor productivity growth in the Arab and developing regions (\%) (1992-2010)

2.23 Average annual labor productivity growth in the Arab region and subregions (\%) (1992-2010)

2.24 Value of inflation rate (consumer price index) in the Arab region (2012)

2.25 Trend of inflation rate (annual change in consumer price index) in the Arab region (2000-2012)

2.26 Average per capita consumption in the Arab countries (2012) 46

2.27 Saving and investment rates in GDP in the Arab countries (\%) (2012)

2.28 Saving and investment gap in GDP in the Arab countries (\%) (2012)

2.29 The share of employment by sectors in the Arab region (2000-2012)

2.30 Labor force participation rate in Arab and World regions (2010) (\%)

2.31 Employment-to-population ratios in Arab and World regions (2013) (\%)

2.32 Youth unemployment and unemployment rates in Arab and World regions (2004-2013) (\%)

2.33 Youth unemployment and unemployment rates in Arab regions (2004-2013) (\%)

2.34 Unemployment rates in Arab regions (2007-2012) (\%)

2.35 The distribution of workers by major occupation in the Arab region (\%)

2.36 The distribution of workers by occupational level in the Arab region (\%)

2.37 Skills gaps proxy estimates for Arab countries (\% of firms that face a skills gap), (2008-2010)

2.38 Educated Arabs high-skilled emigration rates to OECD and GCC countries (2000s) (\%)

2.39 Human capital flight index in the Arab countries score of 1-7 59

2.40 Capacity to retain talents and capacity to attract talents in the Arab region and World countries (2014)

2.41 Capacity to retain talents and capacity to attract talents to the Arab region (2014)

2.42 Capacity to retain talents and capacity to attract talents to the Arab countries (2014)

2.43 Gini index of inequality in the Arab region and developing regions (1990s-2000s)

2.44 Gini index of inequality in the Arab region and subregions (1990s-2000s)

2.45 Poverty incidence in the Arab region and developing regions (1990s-2000s) 
4.1 Skill: Educational attainment levels in the Arab and Advanced World countries (\% of the population aged 25 and above) (2009)

4.2 GERD by sector of performance in Arab countries (2005-2011) (\%)

4.3 GERD and FTER by sectors of employment in Arab countries (2005-2011) (\%)

4.4 GERD by source of funds in Arab countries (2005-2011) (\%) 104

4.5 Global Innovation Index (GII) in the Arab countries (2012-2014) 111

4.6 Innovation efficiency ratio in the Arab countries (2012-2014) 111

5.1 Priorities in Public Spending in the Arab region and World regions and countries (2000-2010)

5.2 Government expenditure on education in the Arab and World countries (2004-2012)

5.3 Illiteracy rates: Adult and youth illiteracy rates in the Arab and World region (2005-2012)

5.4 Distribution of tertiary education student graduates by fields in the Arab and World countries (2010)

5.5 Distribution of tertiary education student graduates by fields in the Arab and World countries (2010)

5.6 Distribution of tertiary education student graduates by fields in the Arab and World countries (2010-2011)

5.7 Distribution of total tertiary education student gross graduation ratio, first degree in the Arab and World countries (2005-2011)

5.8 Gross enrollment in tertiary education in the Arab region and World regions and countries (\%) (2003-2012)

5.9 Gross enrollment in tertiary education in the Arab region and World regions and countries (\%) (2002-2012)

5.10 Secondary education gross enrollment ratio (\%) in the Arab region and World countries (2014)

5.11 Tertiary education gross enrollment ratio (\%) in the Arab region and World countries (2014)

5.12 Quality of the education system in the Arab region and World countries (2014)

5.13 Quality of math and science education in the Arab region and World countries (2014)

5.14 Quality of management schools in the Arab region and World countries (2014)

5.15 Internet access in schools in the Arab region and World countries (2014)

5.16 Availability of research and training services in the Arab region and World countries (2014)

5.17 Extent of staff training in the Arab region and World countries (2014)

5.18 TIMSS results for participating Arab countries (2011) 191

5.19 Student achievement in mathematics and scienceinternational country rankings (2007)

5.20 Skill level defined by educational attainment levels in the Arab and advanced World countries (\%) (2000-2007) 
5.21 Skill level defined by educational attainment levels in the Arab and advanced World countries (\%) (2000-2012)

5.22 Share of World R\&D Expenditures (GERD) by Principal regions/countries (2007) (\%)

5.23 GERD as \% of GDP by Principal regions/countries (2007, 2010-2012)

5.24 R\&D Expenditure (\% of GDP) in the Arab region and World regions and countries (2000-2012)

5.25 Priorities in Public Spending in the Arab region and

World regions and countries (2010-2012)

5.26 Share of World researchers by Principal regions/ countries (2007) (\%)

5.27 Researchers by principal region/countries (per million inhabitants) (2007)

5.28 Total number of researchers in the Arab region and World countries (per million inhabitants) (2010-2012)

5.29 GERD as \% of GDP, Share of World R\&D Expenditures (GERD) and Share of World Researchers

5.30 R\&D (GERD) by sector of performance in the Arab region and World countries (2005-2011) (\%)

5.31 R\&D (GERD) FTE researchers by sector of employment in the Arab region and World countries (2005-2011) (\%)

$5.32 \mathrm{R} \& \mathrm{D}$ (GERD) by source of funds in the Arab region and World countries (2005-2011) (\%)

5.33 Average distribution of R\&D funding resources and FTE researchers in the Arab region (2006-2009) (\%)

5.34 Average distribution of R\&D institutions and FTE researchers in the Arab region (1996) (\%)

5.35 Average distribution of R\&D (GERD) by sector of performance, researchers (FTE), and source of funds in the Arab region (2005-2011) (\%)

5.36 Key ICT indicators: The use of ICT fixed telephone and mobile cellular and fixed (wired) broadband subscriptions (per 100 inhabitants) in the Arab and World regions (2005-2013)

5.37 Key ICT indicators: The use of ICT (Internet) household with computer and households with access to Internet at home (\%) in the Arab and World regions (2005-2013)

5.38 The share of public and private universities in the Arab region (2012) 210

5.39 The share of public and private universities and number of faculty members and students in the Arab region (2012)

5.40 Gross enrollment ratios in tertiary education in the Arab region (\%) (2003-2012)

5.41 Distribution of total tertiary education student gross graduation ratio, first degree in the Arab region (2005-2011)

5.42 The share of tertiary graduates in science, engineering, and technology fields, and other fields in the Arab region (2010-2011) 
5.43 The share of tertiary graduates in science and technology fields, and other fields in the Arab region (2009-2012)

5.44 Priorities of public spending in health, education, and the military in the Arab region (2000-2010)

5.45 Public government spending on education in the Arab region (2004-2012)

5.46 Priorities of public spending in $\mathrm{R} \& \mathrm{D}$, health, education, and the military in the Arab region (2000-2012)

5.47 Priorities of public spending in $\mathrm{R} \& \mathrm{D}$, health, education, and the military in the Arab region (2010-2012)

5.48 Public spending on R\&D in the Arab region (2000-2012)

5.49 The share in total R\&D expenditures, researchers, and publications in the Arab region (2002-2009) (\%)

5.50 The share in total R\&D expenditures and total number of researchers (FTE) in the Arab region (2002-2012) (\%)

5.51 The share in total R\&D expenditures and total number of researchers (FTE) and total graduates in science and engineering in the Arab region (2002-2012) (\%)

5.52 The share in total scientific publications, research papers, and scientific and technical journal articles in the Arab region (2000-2013) (\%)

5.53 Distribution and share of R\&D (GERD) by sector of performance in the Arab region (2005-2011) (\%)

5.54 Distribution and share of R\&D (GERD) by source of funds in the Arab region (2011) (\%)

5.55 Distribution and share of FTE researchers by sector of employment in the Arab region (2005-2011) (\%)

5.56 Distribution and share of $\mathrm{R} \& \mathrm{D}$ funding resources in the Arab region (2006-2009) (\%)

5.57 Distribution and share of R\&D FTE researchers in the Arab region (2005-2009) (\%)

5.58 The share in total Arab use of ICT (Internet, telephone, mobile and fixed [wired] broadband) in the Arab region (2005-2013) (\%)

5.59 The share in total Arab proportion of households with access to the Internet at home and with computer (\%) in the Arab and World regions (2013)

5.60 The share in total Arab use of ICT (Internet, telephone and mobile) in the Arab region (2000-2011) (\%)

5.61 The share in scientific articles published and scientific copublications in the Arab countries (2002-2008) (\%)

5.62 The share in Arab international cooperation in scientific dissemination in the Arab countries (2004)

6.1 Total number of patents applications by nonresidents in the Arab region and World regions (2000-2012)

6.2 Total number of patents applications by residents in the Arab region and World regions (2000-2012) 
6.3 Total number of scientific publications and publication of scientific and technical journal articles in the Arab region and World regions (1996-2012)

6.4 The share of high-technology export (as \% of manufactured exports) in the Arab and World regions (2000-2009)

6.5 Net Foreign Direct Investment Inflow (as \% of GDP) in the Arab and World regions (2000-2012)

6.6 Composite Competitiveness Index, current and intangible Competitiveness Indices in the Arab and comparator countries (2011) 240

6.7 The Global Competitiveness Index: Institutions pillar in the Arab region and World countries (2014)

6.8 The Global Competitiveness Index: Institutions pillar: Property rights and Intellectual property protection in the Arab region and World countries (2014)

6.9 Global Competitiveness Index (GCI) in the Arab region compared to World countries (2011-2014)

6.10 The Global Competitiveness Index and subindex pillars in the Arab region and World countries (2014-2015)

6.11 The Global Competitiveness Index: Innovation pillar in the Arab region and World countries (2014)

6.12 Innovation pillar: capacity for innovation in the Arab region and World countries (2014)

6.13 Global Innovation Index (GII) in Arab region and World regions (2014)

6.14 Innovation input subindex in Arab region and World regions (2014)

6.15 Innovation output subindex in Arab region and World regions (2014)

6.16 Innovation efficiency ratio in Arab region and World regions (2014)

6.17 Innovation quality indicators in Arab region and World regions (2014)

6.18 Composition of innovation quality indicators score in Arab region and World regions (2014) 251

6.19 Innovation and KEI in the Arab and the World region (2012) 254

6.20 Innovation and knowledge index and KEI in the Arab and the World region (2012)

6.21 Innovation and knowledge economy index in the Arab and the World region (2012)

6.22 Total number of scientific publications and publication of scientific and technical journal articles in the Arab region (1996-2012)

6.23 Total number of patent applications by residents and nonresidents in the Arab region (2000-2012)

6.24 The share of high-technology export (as \% of total exports) in the Arab region (2002-2007) 
6.25 The share of total Arab high-technology export (as \% of total exports) in the Arab region (2002-2007)

6.26 The share of high-technology export (as \% of manufactured exports) in the Arab region (2000-2012)

6.27 The share in total Arab high-technology export (as \% of manufactured exports) in the Arab region (2000-2012)

6.28 Net Foreign Direct Investment Inflow (as \% of GDP) in the Arab region (2002-2012)

6.29 The share in total Arab Net Foreign Direct Investment Inflow (as \% of GDP) in the Arab region (2002-2012)

6.30 Global Innovation Index (GII), GII pillars, innovation output subindex, input subindex and efficiency ratio, innovation quality indicators and knowledge indicators score (0-100) in Arab region (2014)

6.31 Innovation efficiency ratio in Arab region (2014)

6.32 Innovation quality indicators in Arab region (2014)

6.33 Composition of innovation quality indicators in Arab region (2014)

6.34 Knowledge indicators in Arab region (2014)

6.35 Innovation and Global Competitiveness Index (GCI) in the Arab region defined by economic structure (2011-2014)

6.36 Innovation and the most problematic factors for doing business in the Arab region defined by economic structure (2014) 



\section{Tables}

2.1 General socioeconomic characteristics of the Arab region compared to other World regions (2005-2013)

2.2 Human development index and its components and general socioeconomic characteristics of the Arab region (2005-2013)

2.3 Sectoral structure of GDP in the Arab countries (2000, 2005, 2011-2012) (\%)

2.4 Sectoral structure of GDP in the Arab countries (2011-2012) (Million \$US dollars) (\%)

2.5 GDP according to spending items in the Arab countries (2000-2012)

2.6 GDP annual growth rate in national currencies (constant and current prices) and in \$US dollars and GDP per capita annual growth rate in the Arab countries (2011-2012)

2.7 GDP per capita annual growth rate in the Arab countries (1995, 2000, 2005, 2008-2012)

2.8 Annual change in consumer price index in the Arab countries (2000, 2007-2012) (\%)

2.9 Average per capita consumption in the Arab countries in 2012 (\%) and the share of domestic saving and investment rates in GDP in the Arab countries in 2012 (\%)

2.10 Unemployment rates in some Arab countries (2007-2012) (\%) and the flexibility of employment relative to economic growth in the Arab countries (2000-2008) (\%)

2.11 Skills gaps proxy estimates for Arab countries (\% of firms which face a skill gap), (2008-2010)

2.12 Poverty incidence, the rate of spending of high to low $20 \%$ of population and child labor in the Arab region

2.13 Lack of social competencies and personal insecurity in the Arab region compared to World region (2004-2013)

2.14 Gender inequality index and gender-related development index in Arab region compared to World region (2000-2013)

4.1 Education and skills index in the Arab countries compared to World regions (1995-2012) 
4.2 S\&T, Research and Development (R\&D), and innovation in the Arab countries as compared to World regions (2002-2012)

4.3 Distribution of GERD, FTER, and sources of funds by sector of performance in the Arab countries (2005-2011) (\%)

4.4 ICT Indicators in the Arab countries as compared to World countries and regions (2005-2013)

4.5 Global Innovation Index (GII), GII pillars, innovation output subindex, input subindex, and efficiency ratio score (0-100) in Arab countries (2014)

4.6 Global Innovation Index (GII) Country Profile: Algeria (2014) 114

4.7 Global Innovation Index (GII) Country Profile: Bahrain (2014) 118

4.8 Global Innovation Index (GII) Country Profile: Egypt (2014) 122

4.9 Global Innovation Index (GII) Country Profile: Jordan (2014) 125

4.10 Global Innovation Index (GII) Country Profile: Kuwait (2014) 128

4.11 Global Innovation Index (GII) Country Profile: Lebanon (2014) 131

4.12 Global Innovation Index (GII) Country Profile: Morocco (2014) 134

4.13 Global Innovation Index (GII) Country Profile: Oman (2014) 138

4.14 Global Innovation Index (GII) Country Profile: Qatar (2014) 141

4.15 Global Innovation Index (GII) Country Profile: Saudi Arabia (2014) 145

4.16 Global Innovation Index (GII) Country Profile: Sudan (2014) 148

4.17 Global Innovation Index (GII) Country Profile: Tunisia (2014) 153

4.18 Global Innovation Index (GII) Country Profile:

United Arab Emirates (2014)

4.19 Global Innovation Index (GII) Country Profile: Yemen (2014) 160

5.1 Priorities in public spending in the Arab region and

World regions and countries (2000-2012)

5.2 Skill level defined by Educational attainment levels (\%)

in the Arab and World countries (2000-2012)

192

5.3 R\&D GERD by sector of performance, employment of FTE researchers and source of funds in the Arab and World countries (2005-2011) (\%)

6.1 The Global Competitiveness Index (GCI), GCI pillar, and innovation pillar in the Arab region and World countries (2014) 244

6.2 Global Innovation Index (GII), GII pillars, innovation output subindex, input subindex, and efficiency ratio score (0-100) in Arab region and World regions (2014)

6.3 Demand for and supply of technologies in the Sudan (1992-2010) (\%)

6.4 Demand for and supply of technologies in the Gulf countries (1989-1998) (\%)

6.5 Demand for and supply of technologies in the Gulf countries (1996-1998) (\%)

6.6 Global Innovation Index (GII), GII pillars, innovation output subindex, input subindex and efficiency ratio, and knowledge indicators score (0-100) in Arab region (2014)

6.7 Implications of poor innovation in knowledge absorption, creation, impact, and diffusion in the Arab countries (2014) 


\section{Preface}

\section{T}

he central themes of this research are the importance of efficient institutions and economic structure for enhancing systems of innovation in the Arab region. The core themes discussed in this study examine the characteristics, causes, and consequences or implications of weak systems of innovation in the Arab region. We use the framework of and perspectives from the "systems of innovation" literature and employ both the descriptive and comparative approaches to provide an empirical investigation of the causes and consequences of poor systems of innovation in the Arab region according to the economic structure, and investigate the relationships between systems of innovation and the economic structure in the Arab region. We highlight the importance of sound policy instruments to improve systems of innovation in the Arab region.

Our results support our first hypothesis, which is that the institutional framework of national and regional systems of innovation in the Arab region are characterized by serious weaknesses as compared with other World regions (in terms of education and higher education, $S \& T$ input indicators $[R \& D$ and human resources in S\&T] and information and communication technology [ICT]). Our findings corroborate our second hypothesis, which is that the structure of the economy has a significant effect in the performance of systems of innovation in the Arab region. The prevalence of a natural resources rent-seeking-based economy in the Arab region has significantly affected the performance of systems of innovation there. Our results support our third hypothesis, which is that the natural resources-based economies (the oil economies, mixed oil economies, and primary export economies) show weak and less dynamic performance in terms of subsystems of education, higher education, and S\&T necessary for the promotion of systems of innovation as compared to the diversified economies in the Arab region. Our findings verify our fourth hypothesis, which is that systems of innovation in the Arab region are hampered and eminently impeded by the weak institutions, inadequate human and financial resources, lack of appropriate economic structure (due to prevalence of natural resources (rent-seeking)-based economies), deficiencies of the labor market, poor social development indicators, and a lack of incentives.

Our results support our fifth hypothesis, which is that poor systems of innovation in the Arab region have serious implications that lead to poor S\&T output indicators (patents, publications, share of high technology exports), foreign direct investment (FDI), competitiveness, global competitiveness index (GCI), global 
innovation index (GII), innovation quality indicators, innovation efficiency ratio, knowledge economy index (KEI), ability to do business, and capacity to create and absorb knowledge as compared to World countries and regions. Our findings support our sixth hypothesis, which is that the natural resources-based economies (the oil economies, mixed oil economies, and primary export economies) have experienced more serious implications when compared to the diversified economies in the Arab region in terms of poor S\&T output indicators (patents, publications, share of high technology exports), FDI, innovation quality indicators or metrics for quality of innovation, innovation efficiency ratio, knowledge and technology output pillar, and knowledge indicators (mainly, knowledge absorption, knowledge creation, and knowledge diffusion).

We find that one serious problematic feature of education, tertiary education, and $R \& D$ in the Arab region is the low and declining share of public spending. Different from the majority of advanced World countries and regions, the priorities in public spending suggest that in the Arab region, spending on health, education, and $R \& D$ has received lower priority as compared to spending on the military. The Arab region is ranked at the top globally in terms of public spending on the military. By contrast, the Arab region is ranked last globally in terms of public spending on both health and R\&D, and second-to-last globally in terms of public spending on education. The share of public spending on the military is nearly two times higher than public spending on both health and education, and nearly sixteen times higher than public spending on R\&D. Since health and education are essential components of human capital and, together with $\mathrm{R} \& \mathrm{D}$ are essential for enhancing productivity and innovation, to improve innovation systems in the Arab region, it is essential for these countries to increase spending on health, education, and R\&D and to reduce spending on the military.

We explain that the two major problems of the subsystem of S\&T and R\&D institutions in the Arab region are the poor S\&T input indicators that are related to low spending on R\&D and inadequate human resources in S\&T, together with the small share of the business enterprise sector and the private sector in R\&D and S\&T efforts. We find that, unlike World advanced countries and regions, in the Arab region the business enterprise sector and the private sector provide a small contribution to $R \& D$ efforts as compared to the government/public and higher education sectors.

In our view, one merit of this research is that the objective of carrying out a current comparative analysis of national innovation systems both within the region and in relation to the rest of the world is quite interesting and relevant. The study discusses a very important issue, not often raised in the existing literature of the Arab world regional system of innovation, with a focus on two key issues: its existence and the implications for the economies of the region. It presents important and timely work consistent with the growing awareness among researchers and policy makers of the region in particular concerning the backwardness of the region in terms of innovation and knowledge for growth and competitiveness.

In our view, another merit is that the study puts the emphasis on the institutional dimension, which is indeed the current single most important factor of the weaknesses of innovation systems in the region, and this is a valuable aspect. Since several 
previous studies in the Arab literature addressed the weaknesses of the institutional dimension of innovation systems from a national perspective, one innovative aspect of this research is that it concentrates on the weaknesses of the institutional dimension from a regional perspective. This study provides an interesting contribution by addressing the reasons why institutions are not working in the Arab region and by explaining that systems of innovation there are eminently impeded by the lack of efficient and appropriate institutions, the lack of appropriate economic structure, and incentives. We provide a more comprehensive investigation since we discuss the problem of poor systems of innovation in the Arab region from two different perspectives, both national and regional, and we provide different interpretations for the impediment factors that inhibit the enhancement of systems of innovation in the Arab region. In our view, another innovative aspect of this research is the presentation of country profiles and an explanation of the strengths and weaknesses of national systems of innovation in the Arab countries from a national perspective.

A further merit of this research is the linking of systems of innovation and economic structure and competitiveness through various indicators, which is not always found in the existing literature. The typology used in this research on the basis of natural resources seems quite useful and helps bring in a real added value, even as links can easily be made between innovation performances and economic dynamics. In our view, the originality and innovative aspects of this research as compared to the existing studies in the Arab literature in the field rest on the use of the typology of the Arab world in four categories to analyze the innovation systems of the region according to certain criteria, mainly, the classification of Arab countries according to the structure of the economy, which differs from the existing studies covering the Arab region that use various classifications of the Arab countries according to income level and geographical location. In our view, this research provides an important contribution and fills a gap in the Arab literature by adopting an interesting comparative approach, by explaining the implications of weak systems of innovation in the Arab region and the relationship between the poor performance of systems of innovation and the structure of the economy in four different categories of countries. We believe that the selection of this criterion is quite consistent with the well-known facts and widely used standard classification of Arab countries according to their reliance on natural resources. A further merit of this research is that it attempts to harness the concept of regional system of innovation and to apply it to the Arab region.

In our view, another merit and innovative aspect of this research is the comprehensive set of recent data used to analyze the innovation systems of the Arab region and to present a more elaborate and comprehensive analysis to assess the causes, consequence, and implications of poor systems of innovation in the Arab region. Moreover, the indicators chosen are fairly conventional and relate to education, S\&T, R\&D, and ICT. Since ICT is vital for the systemic dimension of innovation and has been neglected in the existing work on systems of innovation, we fill the gap in the literature by considering ICT in our analysis of systems of innovation in the Arab region.

Finally, our analysis is useful from a policy perspective and can be used to substantiate useful policy recommendations for enhancing systems of innovation in 
the Arab region. We recommend a firm commitment from policy makers in the Arab region to adopt coherent policy and sound policy instruments for promoting national systems of innovation by putting special emphasis on increasing financial resources and spending on education and R\&D; increasing human investment; enhancing adequate, appropriate, efficient, and systematic institutions by improving institutions of education, higher education, S\&T, and ICT; improving the involvement of business enterprises and the private sector in R\&D, S\&T, and innovation efforts in the Arab countries; and improving the culture and awareness of the importance of R\&D; and enhancing the socioeconomic context and incentives. In addition, we recommend enhancing an appropriate economic structure by implementing comprehensive economic reforms and diversification to help these countries change from the existing "rent-seeking" economic structure to an innovation and knowledge-based economic structure and to help enhance systems of innovation and to achieve inclusive growth and sustainable economic development in the Arab region. 


\section{Acknowledgments}

I sincerely thank Allah, my God, the Most Gracious, Most Merciful for enabling me to complete the writing of this book successfully. I wish to thank all the people who helped me successfully complete this book.

I am delighted to gratefully acknowledge and thank Professor Joan Muysken (Emeritus Professor, Department of Economics, School of Business and Economics, Maastricht University), Professor Bart Verspagen (Director of UNU-MERIT, Maastricht University), Dr. Thomas Ziesemer (Maastricht University), and Professor Bengt-Åke Lundvall (Aalborg University) for introducing me to the systems of innovation approach and for their excellent cooperation and excellent initial comments on earlier drafts of papers that contributed significantly to the improvement and completion of this book.

I am delighted also to gratefully thank the former and current directors of the School of Business and Economics for their kind cooperation and facilitation of my research visit. I gratefully thank Professor Luc Soete (Rector Magnificus, Maastricht University and former Director of UNU-MERIT, School of Business and Economics, University of Maastricht) for both giving me the opportunity to be part of his team of high-quality international research staff and for his continuous support and excellent cooperation. The study presented in this book was conducted at Maastricht Economic and Social Research Institute on Innovation and Technology (UNU-MERIT), School of Business and Economics, Maastricht University, Maastricht, the Netherlands. It was originally prepared during my time as a PhD fellow at UNU-MERIT, Maastricht, the Netherlands (2005), and was revised during my time as a postdoctoral visiting research fellow at UNU-MERIT, Maastricht, the Netherlands (2010-2011). I acknowledge with thanks the host institute at UNU-MERIT, the School of Business and Economics at the University of Maastricht, for the cooperation and hospitality I received during my visiting research fellowship. I am extremely grateful to the host institute for enabling my research visit to benefit greatly from the practical implementation of the approach of the internationalization of research and knowledge, sharing success and learning by doing. I am very grateful to the host institute for giving me the opportunity to be a visiting research fellow affiliated and involved with the truly global, internationally oriented, and prestigious University of Maastricht in the Netherlands. I am 
again grateful to UNU-MERIT and Khartoum University for helping me learn more, improve my understanding, and enhance my capacity, especially in the area of academic production, and for having greatly facilitated and fully supported my research, making it a truly productive, fruitful, and enjoyable experience personally and professionally.

I wish to thank all my colleagues at UNU-MERIT, Maastricht University, for their excellent cooperation during my research visit and for helping me improve my research and share knowledge with outstanding and highly qualified professional academic colleagues from different countries. I am delighted also to gratefully thank all my colleagues in the Economics Department, Faculty of Economic and Social Studies, Khartoum University, for their good support. I wish to extend my thanks to all my Sudanese friends in Maastricht for their good support during my stay in Maastricht, the Netherlands.

The research presented in this book benefited from my learning from the initial comments received on papers presented during several international conferences, training programs, and workshops. I would like to thank the participants and anonymous referees for their good comments that helped me improve my research. I thank the participants at the "Economics of Technological and Institutional Change (ETIC) European Doctoral Training Programme," Maastricht University, Maastricht, the Netherlands (October 2003); "Design and Evaluation of Innovation Policy in Developing Countries Training Programme," UNU-INTECH, Maastricht, the Netherlands (May 2004); "Danish Research Unit for Industrial Dynamics Academy (DRUID) (Winter 2005) PhD Conference,” DRUID Academy, Aalborg, Denmark (January 2005); "Global Network for Economics of Learning, Innovation and Competence Building Systems (GLOBELICS) Academy (2008): PhD School on National Systems of Innovation and Economic Development," GLOBELICS Academy 2008, organized by (GLOBELICS) and Unit for Science, Technology and Innovation Studies, University of Tampere, Tampere, Finland (June 2008); “Tenth GLOBELICS International Conference 2012: 'Innovation and Development: Opportunities and Challenges in Globalisation," Zhejiang University and Tongji University, November 2012, Hangzhou, China; "Eleventh Globelics International Conference 2013: 'Entrepreneurship, Innovation and Economic Development in an Era of Increased Globalisation," Middle East Technical University, Ankara, Turkey (September 2013); "Regional workshop: Developing an Innovation Scoreboard for the MENA region," organized by European Investment Bank, Islamic Educational Scientific and Cultural Organization, and Technology Center at United Nations Economic and Social Commission for Western Asia, Amman, Jordan (March 2015).

I am delighted also to gratefully thank Dr. Jacques Van Der Meer, Managerial Advisor of Projects Directorate, Department of Innovation and Competitiveness at the European Investment Bank (EIB, Luxembourg) and Professor Abulgasem ElBadri, Director of Science and Scientific Research Department, Arab League Educational, Cultural and Scientific Organization (ALECSO, Tunisia) for their excellent cooperation and excellent comments that helped me improve and complete this book. 
I would like to gratefully thank Copyrights and Permissions and Licensing Units, Departments and Secretariats at several international organizations and institutions for their excellent cooperation in arranging for granting a nonexclusive copyright permissions authorizing the reproduction of their data and materials to be used for the sole purpose in this and future editions of this book. I am particularly, extremely grateful to the Organization for Economic Cooperation and Development (OECD), United Nations Educational, Scientific and Cultural Organization (UNESCO) Institute for Statistics (UIS), World Intellectual Property Organization, Cornell University and INSEAD-the Global Innovation Index Report (WIPO-GIIR), World Economic Forum-the Global Competitiveness Report (WEF-GCR), International Labor Organization (ILO), International Telecommunication Union (ITU), and Springer Science+ Business Media.

I am delighted also to gratefully thank Leila Campoli (Editor, Economics and Finance, Palgrave Macmillan), Sarah Lawrence (Editorial Assistant, Economics and Finance, Palgrave Macmillan), and Luba Ostashevsky (Consulting Editor, Palgrave Macmillan), Palgrave Macmillan's anonymous referees, and Palgrave Macmillan's team of high-quality international publication staff for their excellent cooperation and facilitation of the publication of this book.

I thank my grandparents, my aunts, uncles, and their families. Last but not least, my everlasting gratitude, appreciation, and sincere deep thanks to my kind, beloved, wonderful mother, Alawia, and father, Satti; my beloved sisters, Rashida, Khalda, Eiman, and Lana; and my kind brothers, Rashid, Osman, Khalid, Sami, and their families, for their sincere prayers, warm, generous, steady support and faithful encouragement of my long learning journey.

Dr. Samia Satti Osman Mohamed Nour, MAY 20, 2015 



\section{Permissions}

The Study presented in this book was conducted at Maastricht Economic and Social Research Institute on Innovation and Technology (UNU-MERIT), School of Business and Economics, Maastricht University, Maastricht, the Netherlands. The earlier version of papers presented in this book was published with the title "Arab Regional Systems of Innovation: Characteristics and Implications," UNU-MERIT Working Paper 2011-058, Maastricht, the Netherlands, October 2011. The revised version was published with the title "Regional systems of innovation in the Arab region," UNU-MERIT Working Paper 2013-012, Maastricht, the Netherlands, January 2013. All the usual disclaimers apply. The views, analysis and policy recommendations of this book are those of the author and do not necessarily reflect the views and policies of the United Nations University, Maastricht Economic and Social Research Institute on Innovation and Technology (UNU-MERIT), or UNU Affiliated Institutes.

Note for Tables 4.5-4.19: Material originally provided by the World Intellectual Property Organization (WIPO), Cornell University, and INSEAD. The reproduction of this publication has been authorized by the Secretariat of WIPO. This publication is also freely available on WIPO website. WIPO assumes no liability or responsibility with regard to the context of the use of this data.

Note: The study presented in this book obtained permission for the use of some specific materials from several international organization including the Organization for Economic Cooperation and Development (OECD), United Nations Educational, Scientific and Cultural Organization (UNESCO), Institute for Statistics (UIS), World Intellectual Property Organization, Cornell University and INSEAD-the Global Innovation Index Report (WIPO-GIIR), World Economic Forum-the Global Competitiveness Report (WEF-GCR), International Labor Organization (ILO), International Telecommunication Union (ITU), and Springer Science+ Business Media. 



\section{Abbreviations}

$\begin{array}{ll}\text { AKR } & \text { Arab Knowledge Report } \\ \text { ALECSO } & \text { Arab League Educational, Cultural and Scientific Organization } \\ \text { AHDR } & \text { Arab Human Development Report } \\ \text { API } & \text { Arab Planning Institute } \\ \text { AMF } & \text { Arab Monetary Fund } \\ \text { ERF } & \text { Economic Research Forum for the Arab Countries, Iran and Turkey } \\ \text { ESCWA } & \text { Economic and Social Commission for Western Asia } \\ \text { FDI } & \text { Foreign Direct Investment } \\ \text { FTER } & \text { Full-time equivalent researcher } \\ \text { GCC } & \text { Gulf Cooperation Council } \\ \text { GCI } & \text { Global Competitiveness Index } \\ \text { GDP } & \text { Gross Domestic Products } \\ \text { GNP } & \text { Gross National Product } \\ \text { GII } & \text { Global Innovation Index } \\ \text { HDI } & \text { Human Development Index } \\ \text { ICT } & \text { Information and Communication Technology } \\ \text { ILO } & \text { International Labor Organization } \\ \text { IMF } & \text { International Monetary Fund } \\ \text { ISCO } & \text { International Standards Classification of Occupations } \\ \text { IT } & \text { Information Technology } \\ \text { ITU } & \text { International Telecommunication Union } \\ \text { KEI } & \text { Knowledge Economy Index } \\ \text { MBRF } & \text { Mohammed bin Rashid Al Maktoum Foundation } \\ \text { MENA } & \text { Middle East and North Africa } \\ \text { MNC } & \text { Multinational Corporations } \\ \text { NSI } & \text { National Systems of Innovation } \\ \text { OECD } & \text { Organization for Economic Cooperation and Development } \\ \text { R\&D } & \text { Research and Development } \\ \text { RSI } & \text { Regional Systems of Innovation } \\ \text { S\&T } & \text { Science and Technology } \\ \text { TAI } & \text { Technology Achievement Index } \\ \text { UAE } & \text { The United Arab Emirates } \\ \text { UIS } & \text { UNESCO Institute of Statistics } \\ & \end{array}$


UN-ESCWA The United Nations/Economic and Social Commission for Western Asia

UN United Nations

UNCTAD United Nations Conference on Trade and Development

UNDP United Nations Development Programme

UNESCO United Nations Educational, Scientific and Cultural Organization

USPTO US Patent and Trademark office website

WB World Bank

WDI World Development Indicators-World Bank

WEO World Economic Outlook-International Monetary Fund 